\title{
РЕКОНСТРУКЦИЯ ЭТАПОВ И ТЕХНОЛОГИИ СТРОИТЕЛЬСТВА САКСКОГО КУРГАНА ПО МАТЕРИАЛАМ ИССЛЕДОВАНИЙ в МИкрорайоне АЛАТАУ г. АЛМАТЫ
}

\author{
(C) 2020 г. Николай Николаевич Ильдеряков ${ }^{1}$, \\ Сергей Александрович Ярыгин ${ }^{2}$
}

\begin{abstract}
${ }^{1}$ магистр археологии и этнологии, заместитель директора по научной части, TOО «Археологическая экспедиция», Алматы, Казахстан. E-mail: Chuvash_nik@mail.ru; ${ }^{2} \mathrm{PhD}$, научный консультант, TOO «Археологическая экспедиция», Нур-Султан, Казахстан. E-mail: sergeyyarygin80@mail.ru
\end{abstract}

\begin{abstract}
Аннотация. В полевом сезоне 2016 г. на территории микрорайона «Алатау» г. Алматы был исследован курган раннего железного века. Курган был сильно разрушен при строительстве современной инфраструктуры и ограблен. В результате проведенных аварийных раскопок удалось зафиксировать остатки архитектуры и строительные приемы, использовавшиеся при возведении кургана. Особого внимания заслуживает земляная насыпь, в стратиграфическом разрезе которой прослежено не только поочередное перекрывание слоев, но и горизонтальные разнородные тонкие прослойки, вычленяющиеся в каждом из слоев земляной насыпи. На основании полученных данных была проведена визуальная реконструкция кургана и этапов его строительства. Подсчитаны вероятные объемы насыпи и затраченные на ее создание человеко-дни. На основе зафиксированных размеров в исследованной погребальной конструкции произведено вычисление гипотетической единицы измерений,
\end{abstract} используемой при возведении кургана.

Ключевые слова: археология, ранний железный век, курган, архитектура, реконструкция

\section{АЛМАТЫ қ. АЛАТАУ шағын ауданындағы ЗЕРТТЕУ МАТЕРИАЛДАРЫ БОЙЫНША САҚ ҚОРҒАНЫНЫН ҚҰРЫЛЫСЫ КЕЗЕНДЕРІ меН ТЕХНОЛОГИЯЛАРЫН ҚАЙТА ҚҰРУ}

\section{Николай Николаевич Ильдеряков ${ }^{1}$, Сергей Александрович Ярыгин ${ }^{2}$}

\footnotetext{
${ }^{1}$ Археология және этнология магистрі, директордың ғылым жөніндегі орынбасары, «Археологиялық экспедиция» ЖШС, Алматы, Қазақстан. E-mail: Chuvash nik@mail.ru;

${ }^{2} \mathrm{PhD}$ докторы, ғылыми кеңесші, «Археологиялық экспедиция» ЖЖШС, Нұр-Сұлтан, Қазақстан. E-mail: sergeyyarygin80@mail.ru
}

Аннотация. 2016 жылы дала маусымында Алматы қаласының «Алатау» шағын ауданының аумағында ерте темір ғасырының қорғаны зерттелді. Қорған қазіргі инфрақұрылымның құрылысы кезінде әжептәуір бұзылып, тоналған. Өткізілген апаттық қазбалар нәтижесінде, оны салу кезінде пайдаланылған сәулет қалдықтары мен құрылыс амалдарын белгілеу мүмкін болды. Ерекше назарды үйілген топырақ талап етеді, өйткені оның стратиграфиялық кескінінде қабаттардың кезектеп алмасуын 
ғана емес, сонымен қатар үйілген топырақтың әр қабатында бөлінетін көлденең әртүрлі жіңішке қабатшаларды байқауға болады. Алынған мәліметтердің негізінде қорғанның және оның құрылыс кезеңдерін көріп қайта салу жүргізілді. Үйінділердің ықтимал көлемдері мен оған жұмсалған адам-күндер есептелді. Зерттелген жерлеу құрылымында белгіленген өлшемдер негізінде қорғанды салу кезінде пайдаланылатын орташа арифметикалық шама есептелінді.

Түйін сөздер: археология, ерте темір ғасыры, қорған, сәулет, құрылым

\title{
PHASE RECONSTRUCTION and SAKA BARROW BUILDING TECHNOLOGY BASED ON ALATAU microdistrict RESEARCH of ALMATY
}

\author{
Nikolay N. Ilderyakov ${ }^{1}$, Sergey A. Yarygin ${ }^{2}$ \\ ${ }^{1}$ Master of Archeology and Ethnology, Deputy Director for Science, “Archaeological \\ Expedition” LLP, Almaty, Kazakhstan. E-mail: Chuvash_nik@mail.ru; \\ ${ }^{2} \mathrm{PhD}$, Scientific Consultant, “Archeological Expedition” LLP, Nür-Sultan, Kazakhstan. \\ E-mail: sergeyyarygin80@mail.ru
}

\begin{abstract}
Field works were carried out in 2016 to research the Early Iron Age barrow in Alatau microdistrict of Almaty city. The barrow was plundered and significantly destroyed during the modern infrastructure building. As a result of emergency excavations, it was possible to fix the remains of the architecture and construction techniques used in its construction. Of particular note is the earthen embankment, in the stratigraphic section of which there is not only alternating overlapping of layers, but also horizontal heterogeneous thin layers that are isolated in each of the layers of the earthen embankment. Based on the data obtained, a visual reconstruction of the mound and the stages of its construction has been done. Probable volume of earthen mound and labor costs on its construction were estimated. According to the recorded dimensions in the burial structure studied, the hypothetical unit of measurement used in the construction of the mound was calculated.
\end{abstract}

Keywords: archaeology, Early Iron Age, barrow, architecture, reconstruction

\section{Введение}

Курган располагался в северозападной части микрорайона «Алатау» (Медеуский р-н, г. Алматы). Насыпь кургана уплощенно-полусферической формы, сложена из земли и камня. Диаметр сохранившейся части насыпи 27 м, высота 2,9 м. В северозападной части насыпь кургана вместе с подкурганным пространством была повреждена землеройной техникой при строительстве мечети. Забор мечети проходит непосредственно по северо-западной части насыпи кургана. С северо-восточной стороны кургана у основания насыпи проходит современная арычная система, полоса ветрозащитных лесопосадок и автомобильная трасса. В юго-восточной части кургана насыпь до уровня погребенной поверхности переотложена землеройной техникой при посадке деревьев ветрозащитной полосы, палисадника, занимающего всю восточную сторону от кургана, и прокладки действующей арычной системы. С юго-западной стороны в 25 м от насыпи кургана проходит действующий газопровод и автомобильная дорога. На вершине насыпи кургана зафиксирована впадина диаметром до 3,5 м, глубиной до 0,4 м. С восточной стороны от впадины на вершине кургана установлен столб линии оптоволоконного кабеля. В процессе опроса местного населения собраны сведения о возможном разрушении с последующей рекультивацией северной части 
насыпи при строительстве автомобильной трассы. Также насыпь кургана ежегодно использовалась в зимний период в качестве горки для детей. В виду сильного разрушения кургана для фиксации стратиграфии насыпи был выбран наиболее сохранившийся участок по линии Ю3-СВ с возможностью фиксации юго-восточного профиля.

\section{Описание раскопок}

Стратиграфияюго-восточного профиля. Длина профиля 27,5 м, высота 3,3 м. Собранные данные при опросе местного населения относительно полного разрушения северной части насыпи кургана при строительстве автомобильной трассы с последующей рекультивацией - подтвердились. Вся северная и центральная части насыпи в профиле представлены пестрым грунтом светло-коричневого суглинка с включениями линз светло-серого гумусированного суглинка. Исключением является лишь небольшая полоса поврежденного грунта основной насыпи высотой до 0,5 м от уровня погребенной поверхности (рис. 1, 1).

Судя по верхней границе сохранившейся южной части насыпи, курган был ограблен сверху вертикальным грабительским лазом, впоследствии частично засыпанным. Грунт его заполнения идентичен северной разрушенной части профиля. Размеры грабительского лаза в верхней части насыпи составляли не менее 10 м в диаметре. Ближе к погребению грабительский лаз воронкообразно сужается до 5 м в диаметре.

Материковый грунт в профиле представлен темно-серым гумусированным суглинком. В центральной части насыпи, с небольшим смещением в северную сторону, погребенная поверхность прерывается на 5,2 м.
В центральной части насыпи над погребенной поверхностью зафиксированы края основания каменного панциря первичной насыпи. Центральная часть первичной насыпи разрушена грабительским лазом. Судя по оставшимся фрагментам первичной насыпи, диаметр её составлял порядка 12,5 м. Высота сохранившихся фрагментов до 0,8 м, длина до 3,7 м. Насыпь была сложена из пестрого грунта, представленного светлокоричневым суглинком с фракциями светло-серого гумусированного суглинка. Толщина панциря первичной насыпи составляла не менее 0,5 м, он сложен из гальки средних размеров до 25 см в диаметре. Остальную структуру насыпи кургана в профиле можно проследить лишь по сохранившейся южной части.

Первичная каменная насыпь сверху перекрыта шестью дугообразными слоями грунта основной насыпи и каменной крепидой. Особенностью каждого из грунтовых слоев является рыхлость нижней части слоя по отношению к погребению и плотность верхней части. Также прослежен принцип подсыпки грунта при создании нового слоя насыпи, заключающийся в поэтапном спиральном поднятии слоя от основания к вершине. На стратиграфическом разрезе насыпи это отображено чередованием прослоек различных грунтов с сохранением радиального расположения каждого по отношению к погребению.

Первый грунтовый слой основной насыпи представлен темно-серым суглинком с мелкими (до 1 см) включениями светло-коричневого суглинка. Толщина слоя составляет порядка 1 м. Ширина слоя у основания на уровне погребенной поверхности со- 


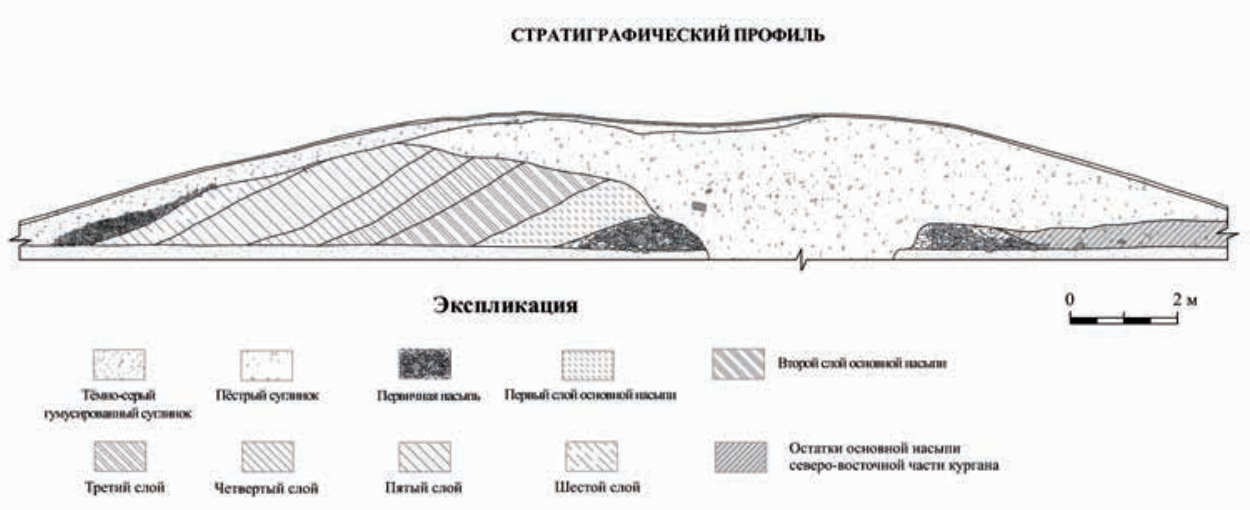

Рис. 1. Алатау. Стратиграфия кургана: 1, 2- северная часть стратиграфического профиля; 3 - чентральная часть стратиграфического профиля

Fig. 1. Alatau. Barrow stratigraphy: 1, 2 - northern part of the stratigraphic profile; 3 - central part of the stratigraphic profile

ставляет 1,9 м, максимальная высота сохранившейся части 1,85 м от уровня погребенной поверхности (рис. 1, 2).

Основу второго слоя также составляет темно-серый суглинок с небольшим количеством линз светлокоричневого суглинка. Длина линз до $50 \mathrm{~cm}$, толщина до $7 \mathrm{~cm}$. Толщина слоя составляет 1,2 м, ширина у основания 2,2 м, максимальная высота сохранившейся части 2,05 м от уровня погребенной поверхности.

Третий слой представлен тем же темно-серым суглинком с большим количеством радиальных прослоек светло-коричневого суглинка толщиной до 10 см. Толщина слоя составляет порядка 0,65 м. Ширина слоя у основания на уровне погребенной поверхности составляет 1,5 м, максимальная высота сохранившейся части 2,25 м от уровня погребенной поверхности.

Структура четвертого слоя представлена чередованием радиальных линз светло-серого гумусированного суглинка и светло-коричневой супеси. Толщина линз до 15 см длина по всей толщине слоя. Толщина слоя составляет 0,7 м, ширина по основанию - 1,5 м, высота сохранившейся части $-2,4$ м (рис. 1,3$)$.

Пятый слой снова более однородный. Основу его составляет светло-коричневый суглинок с линзами светло-коричневой супеси. Линзы супеси расположены хаотично и составляют порядка $40 \%$ всего слоя. Толщина слоя составляет 1,1 м, ширина по основанию - 2,3 м, высота сохранившейся части $-2,4$ м.

Внешний, шестой слой представлен однородным светло-серым гумусированным суглинком. Толщина слоя составляет 0,4 м, ширина по основанию - 0,8 м, высота сохранившейся части - 1,5 м. Данный слой подвергся процессу гумусообразования тем больше, чем ближе он располагался к дерновому слою. У основания насыпи гумусированность слоя слабее вследствие наличия внешней каменной крепиды, однако верхние слои преобразованы в насыщенный темно-серый гумусированный суглинок, перекрывающий всю южную и центральную части насыпи. Толщина верхнего темно-серого гумусирован- 
ного слоя составляет от 0,5 м в районе каменной крепиды основной насыпи, до 10 см в центральной части насыпи. В южной части насыпи гумусированный слой полностью исчезает. Толщина дернового слоя от 1 до 3 см.

Погребальная конструкичия. В центральной части подкурганного пространства, по линии стратиграфического разреза на глубине 0,3 м от уровня погребенной поверхности, была выявлена юго-восточная половина контура погребальной ямы по длинной оси. После разбора северозападной части насыпи кургана в центральной части подкурганного пространства на глубине 0,3 м от уровня погребенной поверхности был полностью расчищен и зафиксирован контур могильной ямы.

Могильная яма прямоугольной формы, вытянута по линии Ю3-СВ. Длина могильной ямы 6,3 м, ширина 2,6 м. Заполнение могильной ямы представлено пестрым грунтом светло-коричневого суглинка с включениями линз светло-серого гумусированного суглинка.

С целью стратиграфических наблюдений заполнения могильной ямы и её конструктивных особенностей, выборка грунта могильной ямы производилась последовательно - сначала в южной части, затем - в северной.

Перед разбором заполнения южной части могильной ямы по внешним границам произведен отступ 10 см к центру ямы для последующего выявления и исследования реальных стен могильной ямы.

В процессе разбора южной части заполнения могильной ямы на глубине 0,6 м от уровня погребенной поверхности в юго-восточном углу найдено три разрозненных фрагмента керамики. Для керамики характерен 64 крупнозернистый песчаный отощитель и некачественный обжиг. На обеих сторонах фрагментов прослежены следы нагара.

По всему периметру могильной ямы выявлены фрагменты древесины и углей различных размеров. Также вдоль длиной северо-западной стенки могильной ямы выявлены разрозненные кости погребенного. Определены фрагменты черепа, запястья, первая фаланга ступни, зуб. На некоторых фрагментах костей присутствует окись зеленого оттенка от соприкосновения с бронзовыми изделиями.

Заполнение могильной ямы, как и грунт грабительского лаза, представлено пестрым грунтом, состоящим из светло-коричневого суглинка с включениями линз светло-серого гумусированного суглинка. После разбора северной части могильной ямы определены границы ее стен. Наибольшая сохранность стен могильной ямы у длинной юго-восточной и короткой северо-восточной стены, где зафиксирован фрагмент частично обгоревшего бревна плохой сохранности. Диаметр бревна составляет порядка 30 см, длина фрагмента - 65 см. Другие стены частично разрушены грабительским лазом. Дно могильной ямы, представленное материковым светлокоричневым суглинком, зафиксировано на глубине 1,9 м от уровня погребенной поверхности.

Судя по конструктивным особенностям в архитектуре насыпи и погребальной конструкции, памятник относится к раннему железному веку. Несмотря на значительные разрушения, удалось зафиксировать ряд элементов насыпи, которые позволяют предложить реконструкцию этапов и приёмов её возведения.

Основные этапы возведения кургана, которые определены по 
структуре насыпи, разделяются на: 1) предварительные работы, которые включали выравнивание площадки, разметку и, вероятно, заготовку материалов; 2) устройство могильной ямы; 3) создание каменной насыпи над могильной ямой; 4) обсыпку каменной насыпи, формирование первого слоя; 5) формирование второго слоя; 6) фор- мирование третьего слоя; 7) формирование четвертого слоя; 8) формирование пятого слоя; 9) формирование шестого слоя; 10) устройство крепиды из камней (рис. 2, 1).

Особого внимания заслуживает земляная насыпь, при сооружении которой прослежено не только поочередное перекрывание слоев, но и го-
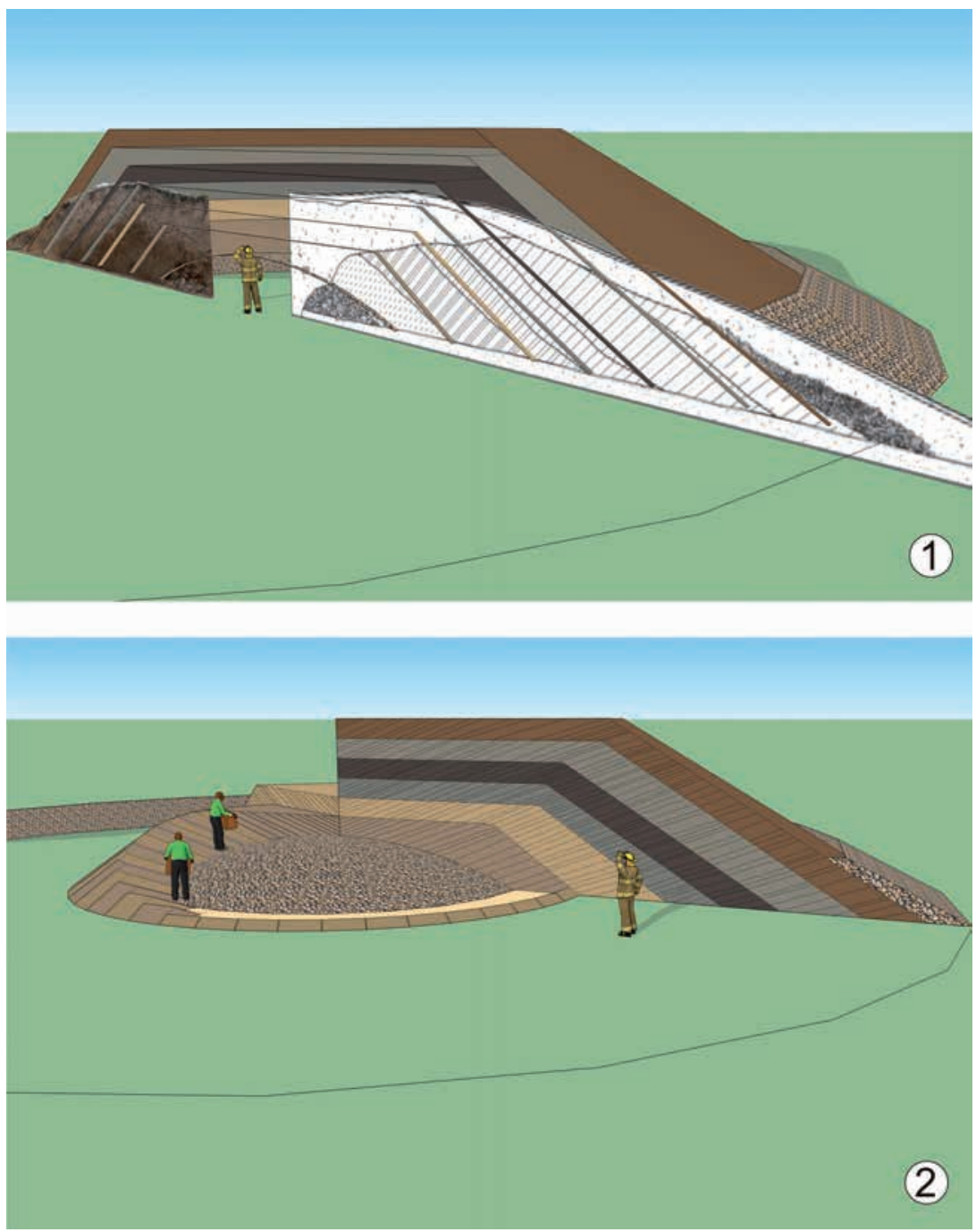

Рис. 2. Алатау: 1 - реконструкция разрушенной части насыпи; 2 - реконструкция технологии формирования грунтовых слоев насыпи

Figure: 2. Alatau: 1 - reconstruction of the destroyed part of the embankment; 2 - reconstruction of the technology for the formation of soil layers of the embankment 
ризонтальные разнородные тонкие прослойки, вычленяющиеся в каждом из слоев земляной насыпи. Разнородность горизонтальных прослоек при сооружении земляной насыпи объясняется применением при сооружении не только верхних окружающих слоев грунта, но и добычей нижних более светлых суглинков из небольших карьеров. Также следует заметить, что горизонтальные тонкие земляные прослойки имеют небольшой уклон к центру кургана и более плотную структуру сформированного ими слоя насыпи.

Все отмеченные особенности позволяют предположить, что после сооружения первичной каменной полусферической насыпи у внешнего
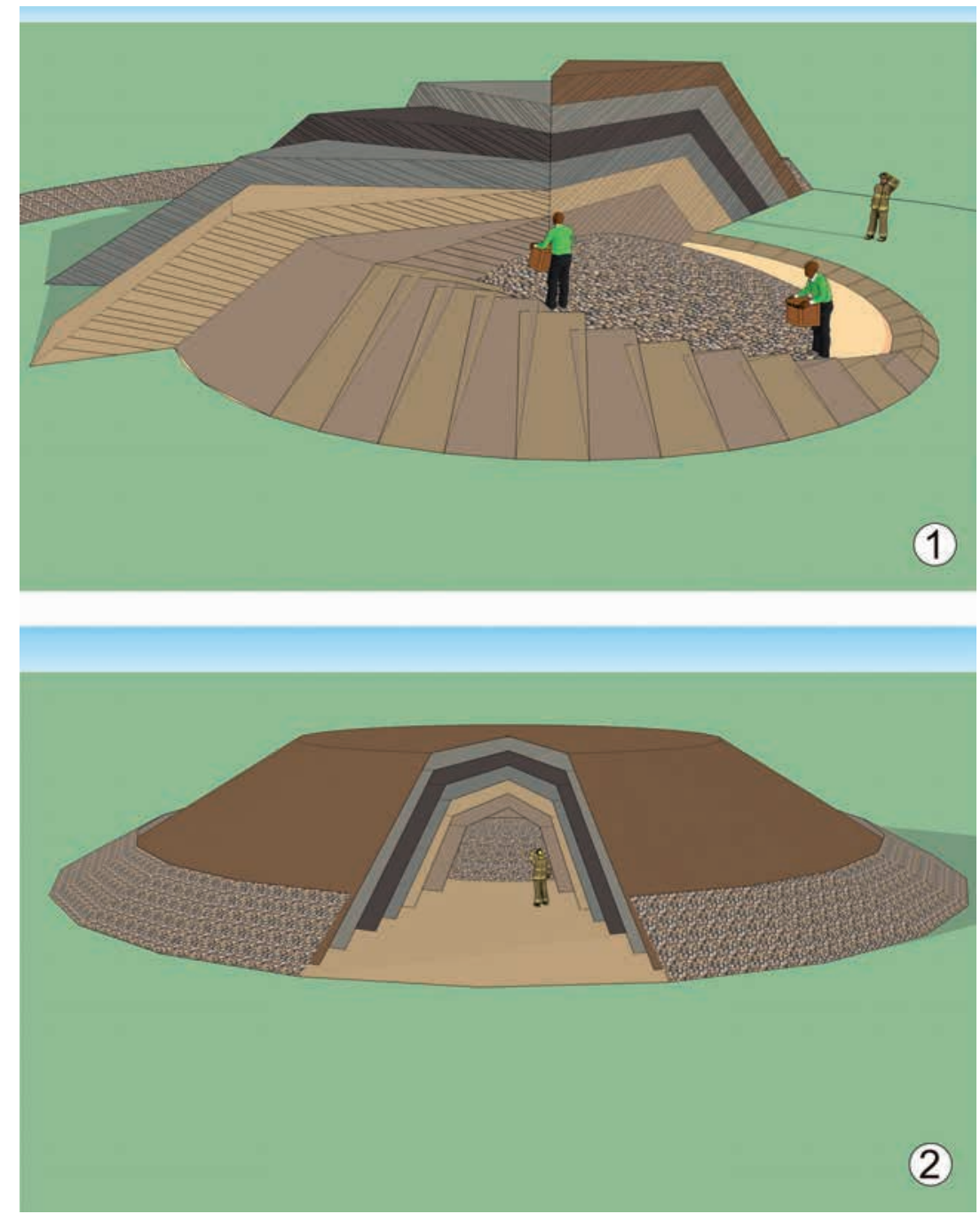

Рис. 3. Алатау: 1 - реконструкиия технологии формирования грунтовых слоев насыпи (приближенный вид);

2 - реконструкция насыпи с разрезом

Fig. 3. Alatau: 1 - reconstruction of the technology of formation of soil

layers of the embankment (approximate view);

2 - reconstruction of the embankment with a cut 
основания было начато возведение спирального земляного трамплина, путем постоянной подсыпки различных по структуре грунтов, образующих плавный спиральный подъем вокруг первичной каменной насыпи (рис. 2, $2 ; 3,1)$. Подобная система возведения имеет ряд явных положительных с практической точки зрения свойств: во-первых, позволяет одновременно задействовать и упорядочить работу большого количества людей путем последовательной конвейерной подсыпки грунта. Во-вторых, дает возможность одновременного сооружения нескольких перекрывающих друг друга земляных слоев надмогильной конструкции. В-третьих, горизонтальные чередующиеся, естественно уплотненные ногами в процессе возведения насыпи земляные прослойки, лучше предотвращают оплыв насыпи.

Уклон горизонтальных земляных прослоек к центру кургана, веро- ятно, был сформирован как с целью безопасности, для предотвращения падений строителей с насыпи, так и уменьшения просыпания грунта за внешние границы слоя насыпи.

Разница плотности грунта в каждом из шести последовательных земляных слоев надмогильной конструкции сформирована искусственно путем уплотнения внешних границ каждого слоя. Равномерные загибы к низу внешних границ тонких горизонтальных земляных прослоек позволяют предположить, что уплотнение производилось сверху вниз массивным катающимся предметом, вероятно, бревном.

Судя по всему, изначальная насыпь представляла собой тип усеченного конуса (табл. 1; рис. 3, 2), что соответствует насыпям средних и крупных сакских курганов региона [Акишев, 2013, с. 56-60].

Таблица 1 - Реконструируемые размеры кургана Алатау

Table 1 - Alatau mound dimensions to be reconstructed

\begin{tabular}{|c|c|c|c|c|c|c|}
\hline $\begin{array}{l}\text { Структурные } \\
\text { элементы }\end{array}$ & $\begin{array}{c}\text { Стратигра- } \\
\text { фический } \\
\text { слой }\end{array}$ & Диаметр & $\begin{array}{c}\text { Толщина } \\
\text { горизон- } \\
\text { тальная }\end{array}$ & $\begin{array}{c}\text { Толщина } \\
\text { радиаль- } \\
\text { ная }\end{array}$ & Высота & $\begin{array}{c}\text { Диаметр } \\
\text { верхней } \\
\text { части }\end{array}$ \\
\hline $\begin{array}{l}\text { Первичный } \\
\text { панцирь }\end{array}$ & - & 12 & - & - & 1,3 & - \\
\hline \multirow{6}{*}{$\begin{array}{l}\text { Земляная } \\
\text { насыпь }\end{array}$} & 1 & 16 & 2,0 & 1,15 & 1,9 & 10,6 \\
\hline & 2 & 21 & 2,5 & 1,35 & 2,5 & 13,5 \\
\hline & 3 & 24 & 1,5 & 0,70 & 3,1 & 13,9 \\
\hline & 4 & 27 & 1,5 & 0,75 & 3,7 & 14,9 \\
\hline & 5 & 31 & 2,0 & 1,05 & 4,3 & 17,1 \\
\hline & 6 & 34 & 1,5 & 0,70 & 4,9 & 17,5 \\
\hline $\begin{array}{l}\text { Каменная } \\
\text { крепида }\end{array}$ & - & 36 & 1,0 & - & 1,5 & 28,4 \\
\hline $\begin{array}{l}\text { Общие } \\
\text { размеры }\end{array}$ & - & 36 & - & - & 4,9 & 17,5 \\
\hline
\end{tabular}


Исходя из реконструируемых размеров, можно произвести вычисление объема и затрат труда (человекодней). Подобная работа была проделана К. А. Акишевым для Семиречья/ Жетысу при реконструкции возведения крупных курганов сакского могильника Бесшатыр [Акишев, 2013, c. 56-60, табл. I-II].

Для расчета объема грунтовой части насыпи можно использовать следующую стандартную формулу расчета объема усеченного конуса: $\mathrm{V}=1 /{ }_{3} \pi \mathrm{H}\left(\mathrm{R}_{1}^{2}+\mathrm{R}_{1} \times \mathrm{R}_{2}+\mathrm{R}_{2}{ }^{2}\right)$. В случае с курганом Алатау формула выглядит следующим образом: $\mathrm{V}=1 /{ }_{3} \times 3,14 \times 4,9$ $\left(17^{2}+17 \times 8,75+8,75^{2}\right)$. Таким образом, объем грунтовой насыпи кургана составляет $2639 \mathrm{M}^{3}$.

Объем каменной крепиды рассчитывается по формуле $\mathrm{V}=\pi / 2 \times \mathrm{H} \times \mathrm{T}\left(\mathrm{D}_{1}+\mathrm{D}_{2}-2 \mathrm{~T}\right)$. Привлекая данные по кургану $\mathrm{V}=3,14 / 2 \times 1,5 \times 1(36+28,4-2 \times 1)$. Объем каменной крепиды достигает 147 м³. $^{3}$.

Учитывая погрешность, в том числе каменную надмогильную конструкцию, объем кургана в 2786 м $^{3}$ можно округлить до 2800 м $^{3}$. Затрата человеко-дней на возведение курганов с таким объемом, по К. А. Акишеву, колеблется от 1000 до 1500 [Акишев, 2013, с. 59, табл. II].

В расчете объемов и трудозатрат на возведение майкопских курганов С. Н. Кореневский за основу рассуждений принимает дневную норму землекопа в 6 м³ $^{3}$ В этом случае подсчет трудозатрат только на насыпку земли принимает вид формулы: $\mathrm{V}$ объем: $6 \mathrm{~m}^{3}=$ РД1. Учет работ на рытье и насыпку этого грунта - V объем: 6 м$^{3} \times 2$ = РД2 [Кореневский, 2010, c. 149-170].

В соответствии с объемом на формирование насыпи кургана Алатау - 2800 м $^{3}: 6$ м $^{3}=467$ человеко- дней, а на насыпку и рытье - $\left(2800 \mathrm{~m}^{3}\right.$ : $\left.6 \mathrm{M}^{3}\right) \times 2=933$ дней и это без учета затрат на доставку камня, дерева и грунта на место строительства. Исходя из полученных данных, можно предложить простейший расчет времени, потраченного на возведение кургана - в среднем коллектив из 100 человек мог завершить работу за 10 дней, 50 строителей затрачивали 20 дней, а группа в 20 человек могла потратить около 50 дней.

Относительно большое количество элементов насыпи кургана позволяет произвести попытку определения измерительных единиц, использовавшимися древними строителями. Однако, естественная деформация насыпи под воздействием ветра и влаги, а также просадка и сползание грунтов заставляет ограничиваться наиболее устойчивыми участками надмогильного сооружения - основанием насыпи над уровнем погребенной поверхности.

Произведя среднее арифметическое значение на основе данных толщины сохранившейся части земляных слоев по основанию насыпи: $(2+2,5+1,5+1,5+2,0+1,5) / 6$ получаем 1,83 м. В качестве проверки можно использовать среднее арифметическое значение, полученное сложением разницы реконструированных диаметров земляных слоев насыпи по основанию: $(4+5+3+3+4+3) / 6=3,66 / 2=$ $1,83 \mathrm{M}$.

В числе дополнительных данных, позволяющих судить о вероятно используемых измерительных единицах, можно использовать размеры могильной ямы $(6,3 \times 2,6 \times 1,9$ м). А в качестве наименьшей доступной реконструируемой единицы измерения можно взять длину грунтовых прослоек, формирующих земляные слои 
насыпи кургана. В нашем случае минимальными значениями обладают грунтовые прослойки третьего и шестого слоя земляной насыпи кургана, длина которых составляет порядка 0,7 м. К ним можно отнести и четвертый слой земляной насыпи. Суммируя имеющиеся данные, вычленяем общее число, делящееся на полученные величины: 1) толщина слоев по основанию: $183 / 6=30,5 \mathrm{~cm} ; 2$ ) размеры могильной ямы: $630 / 20=31,5$ см; $260 / 8=32,5$ см; 190/6=31,6 см; 3) длина грунтовых прослоек: 70/2=35 см. С полученной величиной согласуются и длины грунтовых прослоек, составляющих другие слои земляной насыпи: $115 / 4=28,75$ см; 135/4=33,75 см; $105 / 3=35 \mathrm{~cm}$.
Наиболее близкая современная единица измерения, соотносящаяся с полученным значением - «фут», который, согласно английской системе измерений равен 30,48 см. Следует учитывать, что современная мерная величина фута в различных странах различная, от $25 \mathrm{~cm}$, согласно Римской системе, до 38,3 см согласно Лейпцигской системе. Среднее метрическое значение по данным кургана Алатау - 32 см. Эта мера соответствует определенной И. Л. Кызласовым по материалам кольцевых городищ Минусинской котловины конца I тыс. до н.э. динлинской стопе - 32 см [Кызласов, 2011, c. 27-28].

\section{ЛИТЕРАТУРА}

1. Акишев К.А. Древние и средневековые государства на территории Казахстана (этюды исследования). Алматы: Институт археологии им. А.Х. Маргулана, 2013. $192 \mathrm{c}$.

2. Кореневский С.Н. Феномен больших майкопских курганов: социальнотрудовой и культовый аспекты строительства // КСИА РАН. 2010. Вып. 224. С. 149170.

3. Кызласов И.Л. Кольцевые городища Хакасии. К истории монументальной архитектуры на Енисее (Храмовая архитектура древности). М.: ТАУС, 2011. 64 с.

\section{REFERENCES}

1. Akishev, K. A. 2013. Drevniye i srednevekovye gosudarstva na territorii Kazakhstana (etyudy issledovaniya) (Ancient and medieval states on the territory of Kazakhstan (study studies). Almaty: A.Kh. Margulan Institute of Archeology (in Russian).

2. Korenevskiy, S. N. 2010. In: Kratkie soobshcheniya Instituta arheologii (Brief reports of the Institute of Archeology), 224, 149-170. (in Russian).

3. Kyzlasov, I. L. 2011. Koltsevye gorodishcha Khakasii. K istorii monumentalnoy arkhitektury na Eniseye (Khramovaya arkhitektura drevnosti) (Ring settlements of Khakassia. Towards the history of monumental architecture on the Yenisei (Temple architecture of antiquity). Moscow: "TAUS" Publ. (in Russian).

\footnotetext{
Мүдделер қақтығысы туралы ақпаратты ашу. Авторлар мүдделер қақтығысының жоқтығын мәлімдейді. / Раскрытие информации о конфликте интересов. Авторы заявляют об отсутствии конфликта интересов. / Disclosure of conflict of interest information. The authors claims no conflict of interest. 